\title{
REPATRIACJA/REEMIGRACJA¹ POLAKÓW Z WĘGIER PO ZAKOŃCZENIU II WOJNY ŚWIATOWEJ
}

\author{
Aleksandra Sylburska
}

(1D) http://orcid.org/0000-0002-4969-5048

Uniwersytet Łódzki

\section{ABSTRACT
THE REPATRIATION/RE-EMIGRATION OF POLISH PEOPLE FROM HUNGARY AFTER THE WORLD WAR II

There were many Polish inhabitants in Hungary after the end of the World War II. They were economic emigrants who arrived at the end of the $19^{\text {th }}$ century or refugees who crossed the Polish-Hungarian border in 1939. The goal of Polish representatives in Budapest (diplomats from July 1946) was to organize repatriation/re-emigration which would include both groups. The execution was not easy due to the problems with supplies, lack of money and difficulties to estimate the number of Polish people in Hungary. According to Polish government regime, repatriated people/re-emigrants were to help in rebuilding of the destroyed country, populating it, and developing Recovered Territories, whose status in the first post-war years had not been officially established yet.

Keywords: repatriation, re-emigration, Polish refugees in Hungary, Hungarian Polish Diaspora, Polish diplomacy after 1945, Polish-Hungarian relations.

Słowa kluczowe: repatriacja, reemigracja, polscy uchodźcy na Węgrzech, polska diaspora na Węgrzech, polska dyplomacja po 1945 roku, stosunki polsko-węgierskie.

${ }^{1}$ Pojęcie „repatriacja” odnosi się do Polaków, którzy dotarli na Węgry jako uchodźcy we IX 1939 r. (więcej o polskich uchodźcach w czasie II wojny światowej m.in.: I. Lagzi, Droga żolnierza polskiego przez węgierska granicę w latach 1939-1941, Poznan 1987; eadem, Uchodźcy polscy na Węgrzech w latach II wojny światowej, Warszawa 1980; G. Łu bc zy k, Henryk Stawik. Wielki zapomniany Bohater Trzech Narodów, Warszawa 2008; A. Przew oźni k, Polacy w Królestwie Polskim 1939-1945 - Lengyel menekültek Magyarország területén 1939-1945, Budapest 2006; K. Stasierski, Polscy uchodźcy na Wegrzech w latach 1939-1945, „Przegląd Historyczny” 1961, t. 52, nr 2, s. 247-273; M. Wi eli czko, Polacy na Węgrzech, Lublin 1977). „Reemigracja” dotyczy członków „starej” emigracji, czyli Polaków z zaboru austriackiego osiedlających się nad Dunajem od końca XIX w., którzy przemieszczali się w poszukiwaniu pracy (więcej na ten temat: U. Kaczmarek, Na węgierskiej ziemi. Rzecz o Polonii węgierskiej, Poznań 1999). Największa grupa jej przedstawicieli zamieszkiwała dzielnicę robotniczą Budapesztu Köbánya (ok. 60 rodzin). Pozostałe to przede wszystkim przedmieścia stolicy Óbuda (50 rodzin) oraz leżąca nieopodal niej miejscowość Tatabánya (60 rodzin). Na temat powstania i rozwoju Kőbánya: M. Wieliczko, Köbánya: chtopska, robotnicza dzielnica Budapesztu na przełomie XIX-XX wieku, „Annales Universitatis Mariae Curie-Skłodowska. Sectio F, Historia” 1999/2000, t. 54/55, s. 317-327. 
Podczas II wojny światowej stosunki między Polską a Węgrami nie ustały, chociaż państwa te teoretycznie znajdowały się w dwóch wrogich obozach. Po porażce Polski we wrześniu 1939 roku Węgrzy udzielili schronienia dziesiątkom tysięcy polskich uchodźców, którzy wraz z zakończeniem działań wojennych zaczęli wracać do kraju. Zorganizowanie repatriacji było utrudnione ze względu na brak polskiej placówki dyplomatycznej w Budapeszcie². Dodatkowo na Węgrzech działała Sojusznicza Komisja Kontroli, która, znajdując się pod wpływem Związku Radzieckiego, opóźniała wznowienie stosunków pomiędzy Polską a Węgrami. Pierwszym oficjalnym reprezentantem państwa polskiego po wojnie, oddelegowanym do organizacji procesu repatriacyjnego, był ppłk. Leszek Krzemień. 29 maja 1945 r. został wyznaczony na szefa Delegatury Rządu na Węgry i Austrię. Misję sprawował do końca października 1945 roku $^{3}$.

Kolejnym problemem był brak dokładnych i potwierdzonych danych na temat liczby Polaków nad Dunajem (Węgry znajdowały się na drodze polskich obywateli powracających do kraju z Austrii, Jugosławii i Włoch). Historycy nie są w tej kwestii zgodni, wskazując na wartości pomiędzy 50 a 140 tys. osób ${ }^{4}$. Analiza procesu repatriacji Polaków z różnych zakątków Europy i świata w latach 1945-1950 pozwala dostrzec ogólną zasadę, zgodnie z którą największa liczba powrotów następowała tuż po zakończeniu działań wojennych. Podobną tendencję można było dostrzec w przypadku Węgier: największą liczbę powrotów odnotowano w 1945 roku, wówczas wynosiła ona 25 tys. osób. W kolejnych latach kształtowała się na poziomie: 1946 - 834, $1947-221,1948-28,1949-36,1950-3^{5}$.

W organizacji procesu repatriacyjnego dużą rolę odegrał Komitet Pomocy Repatriantom Polskim na Węgrzech (Komitet), powołany do życia 12 lipca 1945 roku. Jego kierownikiem został Stanisław Spasiński ${ }^{6}$. Dwa dni później Krzemień wygłosił przemówienie w budapesztańskim radio, informując o powstaniu instytucji oraz o pomocy finansowej otrzymanej od węgierskiego rządu w wysokości $15 \mathrm{mln}$ pengő 7 . Prace Komitetu trwały do 15 września 1945 roku, kiedy został zastąpiony Referatem do Spraw Repatriacji przy Delegacie Rządu Polskiego na Węgrzech (Referat),

2 Poselstwo zostało zlikwidowane 1 I 1941 r.: L. Orłow sk i, Wspomnienia z Budapesztu, „Kultura” 1952, nr 10/60, s. 129-135.

${ }^{3}$ J. Królikowski, Generałowie i admiratowie Wojska Polskiego 1943-1990 (I-M), t. 2, red. J. Węgłowska, Torun 2010, s. 293; Archiwum Ministerstwa Spraw Zagranicznych [AMSZ], Biuro Konsularne [BK], 16/44/768, Modzelewski do Krzemienia z 3 XI 1945, k. 1.

${ }^{4}$ A. Przewoźni k, Polacy w Królestwie Polskim..., s. 6.

${ }^{5}$ K. Kerste n, Repatriacja ludności polskiej po II wojnie światowej (studium historyczne), Wrocław 1974, s. 237-238. Dysponujemy raportami Wydziału Konsularnego polskiego poselstwa, na podstawie których można podać inne dane. Z 1946 r. zachowały się raporty wyłącznie z dwóch ostatnich miesięcy, obejmujące 141 osób. W przypadku kolejnych lat dane są kompletne: 1947 - 316, 1948 - 90, 1949 - 80, 1950 - 4. Nie są to jednak dane precyzyjne, ponieważ obejmują często zarówno repatriantów, jak i reemigrantów. Lektura materiałów źródłowych nie pozwala zawsze stwierdzić jednoznacznie, do której grupy Polaków odnoszą się statystyki. Raporty znajdują się w zespole Biura Konsularnego w teczkach o sygnaturach: AMSZ, BK, 20/15/182; AMSZ, BK, 20/15/1037; AMSZ, BK, 20/55/702.

${ }^{6}$ Archiwum Akt Nowych [AAN], Delegatura Polskiej Misji Repatriacyjnej w Budapeszcie [Delegatura PMR], 2/1857/0/-/3, Biuletyn informacyjny z 15 VII 1945, k. 36.

7 AAN, Delegatura PMR, 2/1857/0/-/3, „Polska odrodziła się...”, k. 123. 
będącym delegaturą Polskiej Misji Repatriacyjnej w Wiedniu (PMR w Wiedniu) ${ }^{8}$. Jego siedziba znajdowała się w budynku przy ulicy Andrássy $130^{9}$.

Początkowo dominowały transporty zbiorowe. Jeszcze przed powstaniem Komitetu w dzienniku „Szabad Nép” 10 lipca 1945 roku pojawiła się informacja o przygotowaniu wyjazdu pociągu dla polskich obywateli. Punkt zbiorczy znajdował się przy Hungaria krt. 9, był on przeznaczony dla osób mieszkających w Budapeszcie oraz na prowincji i miał obejmować 12 tys. osób ${ }^{10}$. W ostatnim kwartale 1945 roku można było dostrzec spadek tempa procesu repatriacyjnego, wobec czego ostatni masowy transport repatriantów odbył się 20 października ${ }^{11}$. Od tej pory wydawano indywidualne przepustki, które upoważniały do przejazdu przez granicę czechosłowacką ${ }^{12}$.

Początkowo planowano, że Referat będzie funkcjonował do 1 listopada 1945 roku, okazało się jednak, że na Węgrzech pojawiały się kolejne grupy Polaków, napływających z innych państw. Za zgodą działającej nad Dunajem Sojuszniczej Komisji Kontroli (SKK) oraz przy aprobacie węgierskiego rządu przedłużono jego działalność do 20 listopada, ostatecznie zaś do momentu utworzenia na terenie Węgier polskiej placówki dyplomatycznej ${ }^{13}$.

Popierała ten pomysł reprezentująca PMR w Wiedniu por. Zofia Sielczak, która 20 listopada 1945 roku przeprowadziła w Referacie inspekcję. Dostrzegła pewne nieprawidłowości w działaniu instytucji. W pierwszej kolejności postulowała zmianę kierownika, o co prosił sam zainteresowany ${ }^{14}$. W jej opinii wraz z zakończeniem zbiorowych transportów Spasiński przestał angażować się w pomoc dla Polaków, którzy chcieli powrócić do kraju. Byli kierowani do Bratysławy, brakowało jednak połączenia kolejowego pomiędzy tym miastem a Budapesztem i z powodu tego utrudnienia wielu Polaków decydowało się pozostać na Węgrzech. Należało wznowić organizację transportów zbiorowych ${ }^{15}$. Sielczak przewidywała, że w najbliższym czasie ma przybyć liczna grupa Polaków z Jugosławii, w tym z armii gen. Andersa. Uznała, że Referat powinien wówczas niezwłocznie zawiadomić o tym PMR w Wiedniu, ponieważ nie cieszyli się oni zaufaniem komunistów, którzy zdominowali działający w tym czasie Tymczasowy Rząd Jedności Narodowej ${ }^{16}$. Działalność instytucji była również

${ }^{8}$ AMSZ, Departament Polityczny [DP], 6/120/1802, Spasiński do Czarneckiego z 29 XI 1945, k. 3.

9 Magyar Országos Levéltár [MOL], Lengyelország XIX-J-1-k 1945-1964 [L-XIX-J-1-k], 10. d., 80. t., 945.IV.20, Magyar Vöröszkereszt Országos Központja a Magyar Külügyminisztériumnak (20 IV 1945), brak paginacji.

10 „Szabad Nép”, 10 VII 1945, s. 6. Punkt zbiorczy dla Polaków (a także innych narodowości) był ściśle strzeżony przez radzieckich żołnierzy. Wejście i wyjście były możliwe wyłącznie po okazaniu przepustki: AAN, Organizacje pomocy Polakom i instytucje polskie na Węgrzech, 2/140/0/7/VII_11, Sprawozdanie kierownika sanitarnego Sekcji Polskiej Międzynarodowego Komitetu Czerwonego Krzyża Wawrzyniaka, k. 108.

${ }^{11}$ AMSZ, DP, 6/120/1802, Raport Sielczak z inspekcji w Referacie z 22 XI 1945, k. 7.

12 AMSZ, DP, 6/120/1802, Spasiński do Czarnieckiego z 29 XI 1945, k. 3-4.

13 Ibidem.

${ }^{14}$ AAN, Generalny Pełnomocnik Rządu RP ds. Repatriacji [GP], 2/522/0/-/403, Spasiński do Czarneckiego z 30 XI 1945, k. 41-43.

${ }_{15}$ AMSZ, DP, 6/120/1802, Raport Sielczak z inspekcji w Referacie z 22 XI 1945, k. 7-8.

${ }^{16} \mathrm{O}$ wrogości polskich komunistów do gen. Andersa świadczyły słowa wypowiedziane przez Krzemienia we wspomnianym powyżej przemówieniu z 14 VII 1945 r. Jednocześnie zapewniał on, że jego 
ważna ze względu na konieczność niesienia pomocy około 1100 osobom posiadającym pozwolenie na pobyt. Byli wśród nich studenci, który chcieli dokończyć naukę, oraz osoby, które zawarły związek małżeński z węgierskimi obywatelami ${ }^{17}$.

Pracownicy Komitetu/Referatu wykonywali swoją pracę w trudnych warunkach. Środki finansowe, którymi dysponowali, były niewystarczające, musieli więc poszukiwać innych źródeł pieniędzy na swoją działalność. Udało się uzyskać pomoc od węgierskiego Ministerstwa Opieki Społecznej i wykorzystano ją na zapomogi w gotówce dla podróżujących, wyżywienie dla dzieci w punkcie zbiorczym, transport chorych oraz lekarstwa ${ }^{18}$.

4 grudnia 1945 roku na czele Referatu stanął Zbigniew Kazimirski, dotychczasowy sekretarz Spasińskiego ${ }^{19}$. Już na samym początku urzędowania musiał poradzić sobie z nieporozumieniem, wskutek którego węgierskie MSZ nie dostarczyło Referatowi należnych dostaw produktów żywnościowych od UNRRA. Nie otrzymało ono potwierdzenia, że Referat posiada on zgodę na funkcjonowanie SKK i było przekonane o jego likwidacji. Konieczna była interwencja u przedstawicieli SKK, którzy wydali zgodę na dalszą oficjalną działalność Referatu pod nazwą Polskiej Misji Repatriacyjnej (PMR) ${ }^{20}$.

Kolejnym utrudnieniem był brak pracowników. Kazimirski prosił przełożonych, aby przeznaczyli pewną kwotę na wynagrodzenie dla dwóch kobiet, które pomagały mu w pracy w zamian za wyżywienie ${ }^{21}$. Do codziennych zmartwień należało dodać również brak podstawowych przedmiotów niezbędnych do wykonywania bieżących obowiązków, w tym papieru, kalk czy sprawnych maszyn do pisania ${ }^{22}$. W zniszczonym wojną Budapeszcie brakowało wszystkiego, występowały liczne problemy z zaopatrzeniem mieszkańców w podstawowe produkty, na przykład ubrania. Kazimirski opisywał, że repatrianci są „obdarci”, w związku z czym musiał zwracać się do

żołnierze nie mogli ponosić konsekwencji za popełnione przez niego zbrodnie: AAN, Delegatura PMR, 2/1857/0/-/3, ,Polska odrodziła się...”, k. 123.

17 AMSZ, DP, 6/120/1802, Raport Sielczak z inspekcji w Referacie z 22 XI 1945, k. 8-9.

${ }_{18}$ AMSZ, DP, 6/120/1802, Sprawozdanie Spasińskiego z finansowej działalności Komitetu za okres 12 VII-31 VIII 1945 z 31 VIII 1945, k. 1-2.

19 AMSZ, DP, 6/120/1801, Czarnecki do Kazimirskiego z 4 XII 1945, k. 3; Instytut Pamięci Narodowej Kr [IPN Kr], Wojewódzki Urząd Spraw Wewnętrznych w Krakowie [1945] 1983-1990 [WUSW], 009/79, Życiorys Kazimirskiego z 31 III 1946, k. 10-11. 1 V 1946 r. Zbigniew Kazimirski podjął współpracę z Ministerstwem Bezpieczeństwa Publicznego, pełniąc funkcję informatora o pseudonimie „Solo”. Uważano go za osobę mało energiczną i niewykazującą się inicjatywą, mimo to zdecydowano się na jego werbunek ze względu na dobre rozeznanie w sprawach węgierskich: IPN Kr, WUSW, 009/79, Raport nowo zwerbowanego agenta Zbigniewa Kazimirskiego z 12 V 1946, k. 4; IPN Kr, WUSW, 009/79, Deklaracja współpracy Kazimirskiego z 1 V 1946, k. 5.

${ }^{20}$ AMSZ, DP, 6/120/1802, Kazimirski do Czarneckiego z 1 I 1946, k. 12; Instytut Pamięci Narodowej Biuro Udostępniania [IPN BU], Zarząd II Wydziału Sztabu Generalnego Wojska Polskiego [Z-II-W-SG-WP], 2602/355, Notatka Dudzińskiego dotycząca PMR, k. 75. W archiwum węgierskiego MSZ znajduje się natomiast wiadomość od Krzemienia, w której informuje o zakończeniu procesu repatriacyjnego 1 XI 1945 r.: MOL, XIX-J-1-k 1945-1964 [L-XIX-J-1-k], 10. d., 80. t., 32344/945, Krzemień a Külügyminiszteriumnak (15 IX 1945), brak paginacji.

${ }^{21}$ AMSZ, DP, 6/120/1802, Kazimirski do Czarneckiego z 1 I 1946, k. 12.

${ }^{22}$ AMSZ, DP, 6/26/392, Kobiela do Olszewskiego z 3 VII 1946, k. 1. 
węgierskiej opieki społecznej z prośbą o pomoc w tej sprawie. Czas oczekiwania był długi, ponieważ produktów brakowało często dla Węgrów ${ }^{23}$.

Wśród sukcesów Referatu/PMR można wymienić otwarcie ogrzewanej noclegowni, z której mogło korzystać 10 osób. Została ona uruchomiona w grudniu 1945 roku, co było ważne ze względu na mroźną zimę. Kontynuowano indywidualną repatriację, udzielając 80 przepustek na przełomie lat 1945/1946 ${ }^{24}$. Przedstawione instytucje, chociaż reprezentowały komunistyczną władzę w Polsce, cieszyły się coraz większym zaufaniem Polaków. Przestały pełnić funkcję odpowiedzialnych wyłącznie za kwestie związane z repatriacją. Były postrzegane jako oficjalne przedstawicielstwo państwa polskiego i kierowano do nich wszelkie sprawy związane z polskimi obywatelami, w tym m.in. ponoszenie kosztów leczenia w węgierskich szpitalach ${ }^{25}$.

W Budapeszcie działała Sekcja Polska Międzynarodowego Czerwonego Krzyża (SP MCK). Jeszcze Spasiński zwracał uwagę na trudności w relacjach z jej pracownikami. Twierdził, że jego prośby o wsparcie i udzielenie pomocy materialnej pozostawały bez odpowiedzi ${ }^{26}$. Podobnego zdania był Kazimirski, według którego tylko jeden pracownik SP MCK wykazywał chęć współdziałania i dzięki jego staraniom udało się uzyskać paczki żywnościowe dla polskich studentów oraz chorych ${ }^{27}$. Nie odmawiał jednak pracownikom organizacji chęci niesienia pomocy Polakom. Jako przyczynę tej sytuacji podawał brak odpowiednich funduszy na prowadzenie działalności, z czego mogła wynikać niechęć do dzielenia się skromnymi zasobami $z$ Referatem ${ }^{28}$. Natomiast zupełnie inny powód wskazała Sielczak we wspomnianym raporcie - według niej SP MCK pozostawała w kontakcie z polskim rządem emigracyjnym, czyli była organizacją wrogą przedstawicielom komunistycznej Polski. Nie potrafiła jednak dostarczyć dowodów na potwierdzenie swojej teorii, thumacząc się zbyt małą ilością czasu na dokładniejsze zbadanie sprawy ${ }^{29}$.

Sielczak zwróciła uwagę na liczącą około 15 tys. osób węgierską Polonię ${ }^{30}$. Rozmowy z jej przedstawicielami pozwoliły dojść do wniosku, że niski poziom życia mógłby skłonić wielu z nich do wyjazdu do Polski. Uznała za wskazane rozpoczęcie odpowiedniej pracy propagandowej w celu skłonienia ich do podjęcia tego kro$\mathrm{ku}^{31}$. Zadanie to realizował Kazimirski, udzielając im pomocy materialnej. Uważał, że pozwoli to pozyskać ich zaufanie, niezbędne, by przekonać ich do reemigracji. W grudniu 1945 roku dzięki wsparciu kilku ofiarodawców Referat przygotował paczki

${ }^{23}$ AMSZ, DP, 6/120/1802, Sprawozdanie Kazimirskiego z działalności Referatu za okres 1-25 I 1946 z 28 I 1946, k. 13.

${ }^{24}$ AMSZ, DP, 6/120/1802, Kazimirski do Czarneckiego z 20 XII 1945, k. 11; AMSZ, DP, 6/120/1802, Kazimirski do Czarneckiego z 1 I 1946, k. 12.

${ }_{25}$ AMSZ, DP, 6/120/1802, Sprawozdanie Kazimirskiego z działalności Referatu za okres 1-25 I 1946 z 28 I 1946, k. 16-17.

${ }^{26}$ AMSZ, DP, 6/120/1802, Spasiński do Czarnieckiego z 29 XI 1945, k. 3-4.

27 AMSZ, DP, 6/120/1802, Kazimirski do Czarneckiego z 20 XII 1945, k. 11.

${ }_{28}$ AMSZ, DP, 6/120/1802, Sprawozdanie Kazimirskiego z działalności Referatu za okres 1-25 I 1946 z 28 I 1946, k. 17.

${ }^{29}$ AMSZ, DP, 6/120/1802, Raport Sielczak z inspekcji w Referacie z 22 XI 1945, k. 8.

${ }^{30}$ Por.: przyp. 1.

${ }^{31}$ AMSZ, DP, 6/120/1802, Raport Sielczak z inspekcji w Referacie z 22 XI 1945, k. 8-9. 
świąteczne dla 50 dzieci32 ${ }^{32} 13$ stycznia 1946 roku odbyło się zebranie, w którym uczestniczyli przedstawiciele PMR Kazimirski i sekretarz Ewa Sandor oraz reprezentanci węgierskiej Polonii w Kőbánya. Omówiono wówczas problem opieki nad seniorami i dziećmi, z którym musieli radzić sobie członkowie polskiej diaspory. Przedstawili oni swoje postulaty, prosząc PMR o wsparcie w realizacji planów odnowienia zniszczonego działaniami wojennymi kościoła, organizacji świetlicy oraz szkoły ${ }^{33}$. W pierwszej kolejności udało się otworzyć świetlicę, w której polscy studenci organizowali spotkania na temat historii, geografii oraz literatury polskiej ${ }^{34}$. W styczniu 1946 roku rozpoczęły się lekcje języka polskiego dla dzieci oraz młodzieży, które bardzo często nie potrafiły porozumiewać się w ojczystym języku ${ }^{35}$. Członkowie węgierskiej diaspory docenili starania kierownika PMR i zwrócili się z prośbą do polskich władz, aby był on osobą odpowiedzialną za kwestie polonijne w przyszłym polskim poselstwie ${ }^{36}$.

Kazimirski musiał radzić sobie z problemem przestępczości wśród polskich uchodźców. Na początku 1946 roku informował o procederze związanym z transportem węgla z Polski na Węgry. Często konwojentami byli Polacy, którzy chętnie zatrudniali się do tej pracy ze względu na wysokie wynagrodzenie, ponadto dawała ona możliwość przemycania towarów i uzyskiwania w ten sposób dodatkowego zarobku. Kazimirski chciał zakazać Polakom podejmowania pracy konwojentów, wiedział jednak, z jaką niechęcią spotka się ta decyzja wobec trudnej sytuacji materialnej Polaków na Węgrzech ${ }^{37}$. Miesiąc później informował o przypadkach aresztowań wśród polskich uchodźców, którzy byli podejrzewani o przemyt, handel walutą lub złotem. Ze względu na trudną sytuację finansową Węgier przepisy dotyczące przestępstw gospodarczych były surowe. Kazimirski podjął decyzję, że w tej sytuacji, z uwagi na dobro pozostałych Polaków, PMR nie będzie interweniowała ${ }^{38}$.

Decydenci w Warszawie, w tym przede wszystkim polskie MSZ, uznali, że konieczne jest zakończenie działalności PMR oraz ustanowienie nad Dunajem polskiego przedstawicielstwa dyplomatycznego. Utwierdził ich $\mathrm{w}$ tym przekonaniu przebywający w Budapeszcie w czerwcu 1946 r. polski chargé d'affaires w Rumunii Stefan Wengierow. Zwrócił uwagę na fatalną sytuację materialną pracowników PMR $^{39}$ i postulował, aby niezwłocznie odesłać do Polski Kazimirskiego, który zachorował na gruźlicę. Miał być zastąpiony przez Michała Kobielę, pracownika polskiej placówki dyplomatycznej w Rumunii, którego głównym zadaniem było przygotowanie pomieszczeń dla przyszłego polskiego poselstwa ${ }^{40}$.

${ }^{32}$ AMSZ, DP, 6/120/1802, Kazimirski do Czarneckiego z 1 I 1946, k. 12.

${ }_{33}$ AMSZ, DP, 6/120/1803, Protokół z zebrania przedstawicieli PMR oraz węgierskiej Polonii na Köbánya 13 I 1946, k. 23-24.

${ }^{34}$ AMSZ, DP, 6/120/1802, Kazimirski do Czarneckiego z 1 I 1946, k. 12.

${ }_{35}$ AMSZ, DP, 6/120/1802, Sprawozdanie Kazimirskiego z działalności Referatu za okres 1-25 I 1946 z 28 I 1946, k. 14.

${ }^{36}$ AAN, GP, 2/522/0/-/403, Pismo ks. Oramusa, Hubkiewicza i Żurka z 17 I 1946, k. 9.

${ }^{37}$ AAN, Delegatura PMR, 2/1857/0/-/5, Notatka na temat transportów węglowych z 23 I 1946, k. 52.

${ }^{38}$ AAN, Delegatura PMR, 2/1857/0/-/5, Notatka Kazimirskigo z 16 II 1946, k. 63.

${ }_{39}$ AMSZ, DP, 6/26/397, Wengierow do Olszewskiego z 28 VI 1946, k. 6.

${ }^{40}$ Ibidem. 
Kobiela potwierdził obawy Kazimirskiego o losy Polaków w raporcie z wizyty w Budapeszcie w lipcu 1946 roku. Stwierdził, że prowadzono „antypolską propagandę" w prasie, oskarżając ich o problemy ekonomiczne Węgier ${ }^{41}$. W jego przekonaniu działo się to za przyzwoleniem węgierskich władz. Efektem tego zjawiska były aresztowania, konfiskaty mienia, a nawet pobicia. Kobiela stwierdził, że w Budapeszcie znajduje się grupa „spekulantów”, których główny człon stanowią polscy Żydzi, wcześniej przebywający na terenie Rumunii. Mieli oni uciec na Węgry, gdyż obecność polskiej placówki dyplomatycznej w Bukareszcie ograniczała ich przestępczą działalność ${ }^{42}$. Ataki te ustały tuż przed ustanowieniem w Budapeszcie polskiego przedstawicielstwa dyplomatycznego w lipcu 1946 roku. W opinii jego kierownika chargé d'affaires Piotra Szymańskiego ${ }^{43}$ akcja była efektem działalności licznej grupy „spekulantów i czarnogiełdziarzy” wśród polskich uchodźców, którzy nie zamierzali powracać do kraju. Węgrzy, zmęczeni trudną sytuacją gospodarczą, poszukiwali winnych, których można byłoby obarczyć odpowiedzialnością za panującą inflację. We wrześniu aresztowania ustały, tym bardziej że wielu ,spekulantów" miało już wyjechać $\mathrm{z}$ Węgier, sytuacja finansowa kraju się zaś ustabilizowała ${ }^{44}$.

Kobiela zawarł w raporcie ocenę postawy pozostających nad Dunajem polskich uchodźców - określił ich jako „element bardzo agresywny i bojowniczy”45. Postawa przedstawicieli polskich władz w stosunku do repatriantów ewoluowała. Od początku zwracano uwagę na „,andersowców” (czyli według komunistów - „reakcjonistów" i potencjalnych opozycjonistów), jednak kontrola nad powracającymi Polakami miała się zwiększyć dopiero po utworzeniu polskiego poselstwa. Nie było przypadkiem, że to właśnie Kobiela został wysłany do Budapesztu w celu zapoznania się z sytuacją Polonii. Wcześniej przebywał w Rumunii, gdzie jako członek Polskiego Zjednoczenia Demokratycznego był odpowiedzialny za rozbicie i podporządkowanie

${ }^{41}$ Lektura najważniejszych dzienników z VI 1946 r. wskazuje, że w rzeczywistości opublikowano tylko kilka artykułów dotyczących aresztowania dwóch przemytników: Władysława Wróblewskiego i Jana Słowińskiego, w których mieszkaniu znaleziono obcą walutę oraz przedmioty o dużej wartości (m.in. złotą biżuterię): Izgalmas revolveres hajsza után elfogták Budapesten a lengyel csempészkirályt. 400 billiós értékeket találtak a csempészeknél [Po emocjonującym pościgu z bronią złapano w Budapeszcie polskiego króla przemytników. Znaleziono u niego przedmioty o wartości 400 bilionów], „Világosság”, 6 VI 1946, s. 2; Elfogták a lengyel csempészek büntársait. Töbszáztrilliós értékeket találtak lakásukon [Złapano współpracowników przemytników. W ich mieszkaniu znaleziono przedmioty o wartości ponad stu trylionów], „Világosság”, 9 VI 1946, s. 9; Csempészeket fogott a gazdasági rendőrség [Policja gospodarcza złapała przemytników], „Új Szó”, 6 VII 1946, s. 2; Elfogták a lengyel csempészek büntársait [Złapano współpracowników polskich przemytników], „Új Szó”, 9 VI 1946, s. 2. „Új Szó” był organem prasowym Armii Czerwonej na Węgrzech, a „Világosság” Węgierskiej Partii Demokratycznej.

${ }^{42}$ AMSZ, DP, 6/26/392, Kobiela do Olszewskiego z 3 VII 1946, k. 1-2.

${ }_{43}$ Piotr Szymański spędził wojnę na terenie Rumunii, gdzie był internowany. Angażował się w pracę wśród rumuńskiej Polonii. Po zakończeniu wojny został członkiem PPR i przez kilka miesięcy pracował w centrali MSZ. Pierwszą placówką, którą kierował, było poselstwo w Danii. Został z niej odwołany 30 VI 1946 r., a by kolejnego dnia oficjalnie objąć stanowisko chargé d'affaires W Budapeszcie: A. Sylburska, Działalność polskiej placówki dyplomatycznej na Węgrzech 1946-1956, Łódź 2020, s. $247-248$.

${ }^{44}$ AMSZ, DP, 6/26/397, Szymański do MSZ z 5 IX 1946, k. 10.

${ }^{45}$ AMSZ, DP, 6/26/392, Kobiela do Olszewskiego z 3 VII 1946, k. 2. 
organizacji polonijnych nowej komunistycznej polskiej władzy ${ }^{46}$. Jego umiejętności w tym zakresie potwierdził także Wengierow, pisząc w raporcie: „doświadczenie Kobieli, szczególniej w sprawie nawiązania dobrych stosunków z Rosjanami, w znacznej mierze przyczynić się może do ulżenia sytuacji Polaków oraz do przeprowadzenia wśród nich właściwej czystki".

Wengierow zwracał ,centrali” uwagę na odpowiedni dobór personelu przyszłego poselstwa. Spośród pracowników PMR wskazał jedną osobę, która jego zdaniem spełniania konieczne wymogi: był nią Józef Mazurkiewicz ${ }^{47}$, pełniący funkcję zastępcy kierownika. Proponował również, aby do Budapesztu przybyła jego podwładna Danuta Bereszko, która w Bukareszcie zajmowała się procesem repatriacyjnym ${ }^{48}$. Jego obie sugestie zostały uwzględnione przez polskie MSZ.

Pracownicy powstającego polskiego poselstwa przybyli do Budapesztu wieczorem 6 lipca 1946 roku. Zdecydowano się na wykorzystanie pomieszczenia, które (po przeprowadzce z dotychczasowej siedziby przy ulicy Andrássy 130) zajmowała PMR: 15 sierpnia 1946 roku w domu węgierskich emerytów pocztowych przy ulicy Szent Domonkos 6 umieszczono Wydział Konsularny, przy którym działał Referat Repatriacyjny. W kolejnych miesiącach zmieniał on swoją siedzibę: 10 października mieścił się przy ulicy Benczúr 7, a od 1 listopada - Veres Pálné $9^{49}$. Pierwszym kierownikiem Wydziału Konsularnego został Jan Bikart ${ }^{50}$, natomiast osobą odpowiedzialną za kontynuację repatriacji Mazurkiewicz ${ }^{51}$. Kobiela w pierwszym okresie działania poselstwa zajmował stanowisko kierownika kancelarii. PMR została zlikwidowana 30 lipca 1946 roku. Wszelkie dokumenty, pieczęci oraz druki urzędowe przekazano

${ }^{46}$ Polskie Zjednoczenie Demokratyczne powstało wskutek połączenia w 1945 r. dwóch komunistycznych organizacji - Związku Patriotów Polskich i Komitetu Patriotów Polskich: T. Du bi ck i, Polscy uchodźcy w Rumunii 1939-1945. Studia i materiaty, Warszawa 1995, s. 23, 136; Historia dyplomacji polskiej, t. VI: 1944/1945-1989, red. W. Materski, W. Michowic z, Warszawa 2010, s. 175.

47 Józef Mazurkiewicz złożył deklarację współpracy z MBP 2 VII 1946 r., przyjmując pseudonim „Garwin”. Był postrzegany jako osoba energiczna, dysponująca potencjałem, działająca jednak chaotycznie. Współpraca z MBP trwała do 8 VII 1947 r., kiedy Mazurkiewicz został odwołany z Budapesztu i zatrudniony w MSZ: IPN Ka, Wojewódzki Urząd Spraw Wewnętrznych w Katowicach [1945] 19831990 [WUSW Katowice], 001/437/t. 1, Deklaracja współpracy Mazurkiewicza z MBP z 2 VII 1946, k.4; IPN Ka, [WUSW Katowice], 001/437/t. 1, Raport nr VII nt. „Garwina” z 8 VIII 1946, k. 5; IPN Ka, [WUSW Katowice], 001/437/t. 1, Wniosek o przekazanie teczki osobowej „Garwina” z 8 VII 1947, k. 17; IPN Ka, [WUSW Katowice], 001/437/t. 1, Życiorys Mazurkiewicza, k. 30-31. Brakuje dokumentów określających, jakie były oczekiwania polskich służb bezpieczeństwa wobec Mazurkiewicza. Nie można jednak mieć wątpliwości, że umieszczenie go w Wydziale Konsularnym nie było przypadkowe. Stanowisko to pozwalało kontrolować Polaków przebywających na Węgrzech oraz decydować o tym, kto mógł wrócić do kraju.

48 AMSZ, DP, 6/26/397, Wengierow do Olszewskiego z 28 VI 1946, k. 8.

${ }^{49}$ AMSZ, BK, 20/15/182, Sprawozdanie z działalności Wydziału Konsularnego w okresie 1 VIII-31 XII 1946 z 10 I 1947, k. 2-3.

${ }^{50}$ Okazało się, że Bikart, wyjeżdżając na węgierską placówkę, nie posiadał opinii Urzędu Bezpieczeństwa. Ze względu na charakter swojej pracy, która polegała na wydawaniu paszportów i wiz, każdą jego decyzję musiał zatwierdzać Szymański. Czyniło to pracę Wydziału bardzo nieefektywną: AMSZ, DP, 6/26/392, Szymański do MSZ z 31 X 1946, k. 11.

${ }^{51}$ AMSZ, DP, 6/26/392, Szymański do MSZ z 5 VIII 1946, k. 3. 
Wydziałowi $^{52}$. Okazało się, że PMR nie dysponowała żadnymi środkami finansowymi, które mogłyby być wykorzystane przez pracowników Wydziału ${ }^{53}$.

Wydział wynajmował pomieszczenie, w którym urzędował i ku zaskoczeniu pracowników w sierpniu 1947 roku pojawił się właściciel, który zabrał z sobą część mebli, w tym: półki na akta, stoły, krzesła, stoliki pod maszyny do pisania, a nawet świecznik. Ówczesny kierownik Wydziału określił eufemistycznie te warunki jako „niewystarczające”. Z powodu braku mebli dokumenty leżały na podłodze, wskutek czego panował w nich bałagan. Brakowało również wygodnego stanowiska pracy dla stenografistek $^{54}$.

Na początku urzędowania Szymański szacował, że liczba uchodźców wojennych wynosi około 3 tys. osób. Ponadto wspominał o liczącej około 15 tys. węgierskiej Polonii, pamiętając, jakie były oczekiwania polskiej władzy wobec tej grupy. Zdecydowana jej większość potrzebowała pomocy materialnej, część natomiast rozważała wyjazd do Polski ${ }^{55}$. Dokończenie procesu repatriacyjnego i reemigracyjnego było jednym z priorytetowych zadań polskiego poselstwa. Problem ten nabrał dodatkowego znaczenia po przemówieniu amerykańskiego sekretarza stanu Jamesa Byrnesa 6 września 1946 roku, w którym odniósł się do problemu granicy polsko-niemieckiej. Podkreślił w niej tymczasowy charakter polskiej obecności na Ziemiach Odzyskanych, czym wywołał niepokój zarówno polskiej władzy, jak i społeczeństwa. Z kolei brytyjski minister spraw zagranicznych Ernest Bevin 22 października 1946 roku powiedział, iż przyznanie Polsce tak obszernych terenów może nastąpić dopiero wówczas, gdy udowodni, że może je skutecznie zagospodarować. Polskie władze uznały, że w tym momencie było to najważniejsze zadanie do wykonania, aby zażegnać ryzyko utraty Ziem Odzyskanych ${ }^{56}$.

We wrześniu 1946 roku attaché prasowy polskiego poselstwa rozpoczął akcję propagandową mającą skłonić Polaków do powrotu do kraju i pomocy w zagospodarowywaniu poniemieckich terenów. Przygotowano tablice z informacjami oraz fotografiami Ziem Odzyskanych, które umieszczono w poczekalni placówki. Wydano biuletyn, w którym zachęcano do wyjazdu. Akcja była prowadzona również w prasie i radio. Pracownikom poselstwa zależało na tym, aby dotrzeć do Polaków mieszkających w Budapeszcie oraz na prowincji ${ }^{57}$.

Starania polskiej placówki przyniosły początkowo efekt i 7 listopada 1946 roku ruszył pierwszy transport zbiorowy składający się z 5 wagonów ${ }^{58}$. W czerwcu 1947 roku Wydział zorganizował dwa przejazdy koleją dla 15 Polaków ${ }^{59}$. Kolejny zbiorowy transport odbył się w lipcu 1947 roku: w 18 wagonach do Polski powróciło wówczas 128 osób, zabierając z sobą cały ruchomy dobytek. Do transportów zgłaszali się nie

\footnotetext{
${ }^{52}$ AAN, Delegatura PMR, 2/1857/0/-/5, Falewski do Kazimirskiego z 30 VII 1946, k. 119.

3 AMSZ, DP, 6/26/398, Szybek do Wiernej z 25 VIII 1946, k. 6.

${ }^{54}$ AMSZ, BK, 20/15/182, Sprawozdanie Kościńskiego za okres 1 VII-30 IX 1947 z 20 X 1947, k. 60.

${ }_{55}$ AMSZ, DP, 6/26/392, Szymański do MSZ z 5 VIII 1946, k. 3.

56 W. Dobrzy cki, Granica zachodnia w polityce polskiej 1944-1947, Warszawa 1974, s. 67-75.

${ }^{57}$ AMSZ, DP, 6/26/400, Raport prasowy za okres 1-15 IX 1946 z 17 IX 1946, k. 74-75.

${ }^{58}$ AMSZ, BK, 20/37/439, Raport konsularny nr 5 sporządzony przez Bikarta 3 XII 1946, k. 11.

${ }^{59}$ AMSZ, BK, 20/15/182, Sprawozdanie Kościńskiego za VI 1947 z 3 VII 1947, k. 23.
} 
tylko uchodźcy wojenni (chociaż stanowili większość podróżujących), ale również członkowie węgierskiej Polonii ${ }^{60}$. Okazało się jednak, że w kolejnych miesiącach Polacy zaczęli zgłaszać się w zbyt małych grupach w dużych odstępach czasu, co utrudniało organizację transportu zbiorowego. Zdecydowano o wprowadzeniu zasady, zgodnie z którą darmowe przejazdy będą organizowane dla przynajmniej 10 osób zgłaszających się w tym samym czasie. W innym razie chętni musieli podróżować do kraju na własną rękę, chociaż zdarzały się przypadki, kiedy Wydział wspierał finansowo najbardziej potrzebujących ${ }^{61}$.

W marcu 1949 roku został ogłoszony nabór do transportu, który miał ruszyć latem. Warunkiem jego organizacji było zgłoszenie się 150 osób. Był to ostatni darmowy transport, w którym uczestnicy mogli zabrać cały majątek ruchomy ${ }^{62}$. Przygotowania przedłużyły się aż do 21 października 1949 roku, należało jednak uznać za sukces fakt, że transport w ogóle się odbył, ponieważ ze 100 chętnych na podróż zdecydowało się ostatecznie tylko 65 osób $^{63}$.

Ostatni transport zbiorowy poprzedzony był intensywną akcją propagandową. W przekonaniu ówczesnego kierownika Wydziału Henryka Kościńskiego w połowie 1949 roku władzom węgierskim zależało na tym, aby do Polski wyjechało jak najwięcej uchodźców wojennych, wobec których ich stanowisko było nieprzychylne (ze względu podejrzewanie ich o „reakcyjne” poglądy ${ }^{64}$. Sytuacja zmieniła się $\mathrm{w}$ drugiej połowie roku. W związku z ogłoszeniem na Węgrzech pięcioletniego planu gospodarczego (1950-1954) zaczęto inaczej traktować Polaków nad Dunajem - brakowało rąk do pracy niezbędnych do wykonania planu, dlatego węgierskie władze były gotowe zatrudnić polskich uchodźców wojennych w różnych gałęziach przemysłu. Planowały również pozyskać ich na stałe, nadając im węgierskie obywatelstwo. W związku z tym pracownicy Wydziału zdecydowali się na zmianę taktyki, czyli ubieganie się o tych przedstawicieli polskiej emigracji, którzy byliby w stanie dostosować się po powrocie do kraju do panującego w Polsce reżimu komunistycznego ${ }^{65}$.

Osobną grupą byli przedstawiciele węgierskiej Polonii. Węgierska władza odnosiła się do nich pozytywnie i nie naciskała na ich reemigrację, traktując ich jako część węgierskiego społeczeństwa. Pracownicy polskiego poselstwa nie ustawali jednak w próbach przekonania ich do wyjazdu do kraju. W tym celu nie zawahali się również wykorzystać przedstawicieli polskiego Kościoła katolickiego, wiedząc, jak silny

${ }^{60}$ AMSZ, BK, 20/15/182, Sprawozdanie Kościńskiego za okres 1 IV-30 VI 1947 z 10 VII 1947, k. 51; AMSZ, BK, 20/15/182, Sprawozdanie Kościńskiego za okres 1 VII-30 IX 1947 z 20 X 1947, k. 66.

${ }^{61}$ AMSZ, BK, 20/15/182, Sprawozdanie Kościńskiego za okres 1 X-31 XII 1947 z 10 I 1948, k. 85; AMSZ, BK, 20/78/1037, Sprawozdanie Kościńskiego za okres 1 X-31 XII 1949 z 15 I 1950, k. 7-8.

${ }^{62}$ AMSZ, BK, 20/15/182, Sprawozdanie Kościńskiego za okres 1 I-31 III 1949 z 12 IV 1949, k. 167-168; AMSZ, BK, 20/15/182, Sprawozdanie Kościńskiego za okres 1 VII-30 IX 1949 z 15 X 1949, k. 195v; MOL, L-XIX-j-1-k, 10. d., 80. t., 75.354-1947, brak paginacji.

${ }_{63}$ AMSZ, BK, 20/15/182, Sprawozdanie Kościńskiego za okres 1 VII-30 IX 1949 z 15 X 1949, k. $195 \mathrm{v}$.

${ }^{64}$ AMSZ, BK, 20/15/182, Sprawozdanie Kościńskiego za okres 1 IV-30 VI 1949 z 15 VII 1949, k. 186.

${ }^{65}$ AMSZ, BK, 20/15/182, Sprawozdanie Kościńskiego za okres 1 VII-30 IX 1949 z 15 X 1949, k. 196. 
wpływ posiadał on na swoich wiernych, w większości niezamożnych robotników o konserwatywnych poglądach ${ }^{66}$. Z tego powodu zdecydowano się na "taktyczną" współpracę z proboszczem parafii ks. Erazmem Malczykiem, wspierającym z ambony akcję propagandową na rzecz reemigracji. Ponadto wysłano dwóch robotników z leżącej nieopodal Budapesztu osady górniczej Tatabánya do Polski, aby zapoznali się z panującymi w niej warunkami życia, a następnie podzielili się wrażeniami z członkami węgierskiej Polonii ${ }^{67}$.

W pierwszej połowie 1950 roku zagadnienie repatriacji przestało być priorytetem dla polskiego poselstwa. Zainteresowanie Polaków wyjazdem do kraju wyraźnie zmalało (w drugim kwartale zdecydowała się na to jedna osoba). Pozostali na Węgrzech Polacy należeli przede wszystkim do „dawnej” emigracji, byli silnie zasymilowani z węgierską społecznością. Pięć lat po zakończeniu wojny sytuacja gospodarcza Węgier poprawiła się, co utrudniało polskim dyplomatom prowadzenie skutecznej akcji propagandowej. O pozostałych Polakach, którzy wywodzili się z emigracji wojennej, Kościński wyrażał się krytycznie. W jego opinii nie należało zabiegać o ich powrót do kraju ze względu na fakt, że byli „zupełnie bezwartościowi" ${ }^{68}$ (co należało rozumieć jako postawę niechętną systemowi komunistyczne$\mathrm{mu}$, ewentualnie podejrzenia o niedozwoloną działalność gospodarczą). Poza tym oni sami nie wyrażali chęci powrotu ze względu na przychylny stosunek węgierskich władz, sympatię społeczeństwa, a także stabilizację finansową ${ }^{69}$.

Wraz z zakończeniem procesu repatriacji i reemigracji przed pracownikami polskiego poselstwa pojawiły się nowe zadania. Po pierwsze, mogli od tej pory dokładniej kontrolować osoby, które ubiegały się o powrót do kraju. Wraz z początkiem 1951 roku Kościński postanowił zwracać się do MSZ w przypadku wątpliwości co do intencji potencjalnych repatriantów/reemigrantów, wyrażając swoją opinię i prosząc „centralę” o decyzję. Wynikało to z jego obaw, że pośród osób ubiegających się o powrót będzie coraz więcej tych, które „od strony politycznej, a często i moralnej" budzą zastrzeżenia ${ }^{70}$. Poza tym brak perspektyw co do wyjazdu pozostałych przedstawicieli węgierskiej Polonii skutkował tym, że polskie poselstwo musiało roztoczyć nad nimi kontrolę. Początkowo oznaczało to zintegrowanie ich w ramach

${ }^{66} \mathrm{Na}$ temat roli polskiego kościoła w Köbábya: M. Józe fow i c z, Kościót Polski w Budapeszcie, Budapeszt 2002; U. Kaczmarek, Na węgierskiej ziemi, s. 53-64; Powstanie i rozwój parafii, „Quo Vadis. Polska Parafia pw. Matki Bożej Wspomożycielki Wiernych w Budapeszcie” 2008, wyd. specjalne „Kościół i Dom Polski w Budapeszcie”, s. 3-17.

${ }^{67}$ Kościński tłumaczył fiasko ostatniej zbiorowej akcji repatriacyjnej działalnością „,wrogiej szeptanej propagandy”, którą mieli rzekomo szerzyć pozostający wciąż na Węgrzech polscy „reakcjoniści” (przyznawał jednak, że nie posiadał dowodów na poparcie swojej tezy): AMSZ, BK, 20/5/70, Sprawozdanie Kościńskiego za okres 22 III-31 XII 1949 z 7 II 1950, k. 5-6. W przeszłości jednak znane były przypadki polskich robotników, którzy po przybyciu do Polski nie mogli znaleźć pracy i powracali na Węgry, zniechęcając potencjalnych chętnych do wyjazdu: IPN BU, Z-II-W-SG-WP, 2602/262, Wyciąg z raportu nt. emigracji polskiej na Węgrzech z 14 IX 1946, k. 32.

${ }_{68}$ AMSZ, BK, 20/78/1037, Sprawozdanie Kościńskiego za okres 1 IV-30 VI 1950 z 10 VII 1950, k. 45.

${ }_{69}$ AMSZ, BK, 20/21/258, Sprawozdanie Kościńskiego za okres 1 VII-31 XII 1949 z 27 II 1951, k. 57.

70 AMSZ, BK, 20/55/702, Sprawozdanie Kościńskiego za okres 1 I-31 III 1951 z 14 IV 1951, k. 28. 
jednej organizacji polonijnej, następnie zaś jej rozwiązanie i „likwidację zagadnienia polonijnego" $"$.

\section{BIBLIOGRAFIA}

\section{Materiały archiwalne}

Archiwum Akt Nowych

Delegatura Polskiej Misji Repatriacyjnej w Budapeszcie

Generalny Pełnomocnik Rządu RP ds. Repatriacji

Organizacje pomocy Polakom i instytucje polskie na Węgrzech

Archiwum Ministerstwa Spraw Zagranicznych

Biuro do Spraw Repatriacji

Biuro Konsularne

Departament Polityczny

Instytut Pamięci Narodowej

Wojewódzki Urząd Spraw Wewnętrznych w Katowicach [1945] 1983-1990

Wojewódzki Urząd Spraw Wewnętrznych w Krakowie [1945] 1983-1990

Zarząd II Wydziału Sztabu Generalnego Wojska Polskiego

Magyar Országos Levéltár

Külügyminisztérium: Lengyelország 1945-1964

\section{Prasa}

„Szabad Nép”, 10 VII 1945

„Világosság”, 6 VI 1946, 9 VI 1946

„Új Szó”, 9 VI 1946, 6 VII 1946

71 AMSZ, BK, 20/5/70, Kościński do Wydziału do Spraw Polonii Zagranicą z 1 IX 1950, k. 29. Więcej na temat postępowania polskiej placówki dyplomatycznej wobec organizacji polonijnych: A. Sy lburska, Akcja polskiej placówki dyplomatycznej na Węgrzech wobec „reakcyjnych” organizacji polonijnych (1946-1950), „Acta Universitatis Lodziensis, Folia Historica” 2014, nr 93, s. 99-117. 


\section{Opracowania}

Dobrzycki W., Granica zachodnia w polityce polskiej 1944-1947, Warszawa 1974.

Dubicki T., Polscy uchodźcy w Rumunii 1939-1945. Studia i materiały, Warszawa 1995.

Historia dyplomacji polskiej, t. VI: 1944/1945-1989, red. W. Maters ki, W. Michowicz, Warszawa 2010.

Kaczmarek U., Na węgierskiej ziemi. Rzecz o polonii węgierskiej, Poznań 1999.

Kersten K., Repatriacja ludności polskiej po II wojnie światowej (studium historyczne), Wrocław 1974.

Królikowski J., Generałowie i admirałowie Wojska Polskiego 1943-1990 (I-M), t. 2, red. J. W ęgłow ska, Toruń 2010

Lag zi I., Droga żotnierza polskiego przez węgierska granicę w latach 1939-1941, Poznań 1987.

Lagzi I., Uchodźcy polscy na Węgrzech w latach II wojny światowej, Warszawa 1980.

Łubczyk G., Henryk Stawik. Wielki zapomniany Bohater Trzech Narodów, Warszawa 2008.

Orłowski L., Wspomnienia z Budapesztu, „Kultura” 1952, nr 10/60, s. 115-136.

Powstanie i rozwój parafii, „Quo Vadis. Polska Parafia pw. Matki Bożej Wspomożycielki Wiernych w Budapeszcie” 2008, wyd. specjalne „Kościół i Dom Polski w Budapeszcie”, s. $3-17$.

Przew oźnik A., Polacy w Królestwie Polskim 1939-1945 - Lengyel menekültek Magyarország területén 1939-1945, Budapest 2006.

Stasierski K., Polscy uchodźcy na Węgrzech w latach 1939-1945, „Przegląd Historyczny" 1961, t. 52, nr 2, s. 247-273.

Sylburska A., Akcja polskiej placówki dyplomatycznej na Wegrzech wobec ,reakcyjnych” organizacji polonijnych (1946-1950), „Acta Universitatis Lodziensis, Folia Historica" 2014, nr 93, s. 99-117.

Sylburska A., Działalność polskiej placówki dyplomatycznej na Wegrzech 1946-1956, Łódź 2020.

W i l l i z z o M., Köbánya: chłopska, robotnicza dzielnica Budapesztu na przełomie XIX-XX wieku, „Annales Universitatis Mariae Curie-Skłodowska. Sectio F, Historia” 1999/2000, t. 54/55, s. 317-327.

Wieliczko M., Polacy na Wegrzech, Lublin 1977. 
